\title{
Chapter 5 \\ Implications of Globalization on Growing External Debt in Eight Transition Economies
}

\author{
Marko Jeločnik \\ Institute of Agricultural Economics, Serbia \\ Jovan Zubovic \\ Institute of Economic Sciences, Serbia \\ Mihajlo Djukic \\ Institute of Economic Sciences, Serbia
}

\begin{abstract}
External debt accumulation is a common feature of transition economies during the process of economic transformation. Insufficient domestic resources and low savings as typical problems in these countries have to be fulfilled through some form of external capital. This chapter analyzes determinants and trends of external borrowing in eight transition European economies. It is shown that despite a positive correlation between external debt and economic growth in the initial phases of transition, its further accumulation is associated to higher risks in terms of macroeconomic stability. This has also been proved during the recent economic crisis when external debt in most of countries recorded sharp rise. If further trends of rising external debt accumulation continue, observed economies might face serious economic problems related to debt repayment and lower growth perspectives.
\end{abstract}

\section{INTRODUCTION}

After the political changes in 1989, Central and Eastern European countries (CEE) started processes of political and economic transformation aiming to catch up with the developed Western economies. One of the main economic issues that CEE economies faced during the transition period was how to provide financial resources for the economic development. Due to insufficient domestic resources and low savings, those countries were mainly oriented on external sources of capital.

DOI: 10.4018/978-1-5225-0451-1.ch005

Copyright $\odot$ 2016, IGI Global. Copying or distributing in print or electronic forms without written permission of IGI Global is prohibited. 
In this chapter, the authors aim to analyze the external debt dynamics in the eight transition economies - Bulgaria, Croatia, Czech Republic, Hungary, Romania, Slovakia, Slovenia, and Serbia, in the period 1991-2014. The external debt situation within this group of countries differs strongly from the very beginning of the transition period. Poland, Hungary, and Bulgaria were running large foreign debt at the beginning of the 1990s, inherited from the communist period. While Poland owed mainly towards official creditors, Hungary and Bulgaria were indebted to commercial banks (Manzocchi, 1997). Other countries such as Former Yugoslav countries and Czechoslovakia accumulated debt during the communist period, although not having such an unfavourable starting point. Problems in those countries arose later during the transformation period. Croatia is now one of the most indebted countries with a strong reliance on external borrowing from unaffiliated lenders. Croatia, Hungary, and Serbia are demonstrating vulnerability on multiple fronts with an external debt to GDP ratio higher than $90 \%$ (International Monetary Fund, 2014a). Romania started transition period with a low external debt to GDP ratio. In fact, Romania used to take credits abroad during the 1970s, but decided to repay external creditors including multilateral lenders in advance, during the 1980s (Buiter \& Lago, 2001). During that period, citizens paid terrible price of lowered consumption and imports. However, external sustainability worsened significantly during the period of global financial crisis. In the period 2007-2013, external debt recorded sharp increase while institutional creditors have been replaced by private ones (Milea, 2014). According to International Monetary Fund (2014a) data, Romania had external debt to GDP ratio above $70 \%$. In summary, countries with the highest external debt exposure in the public sector at the moment include Hungary and Serbia, while countries with the highest external debt exposure in the private sector include Hungary, Bulgaria, and Croatia.

It could be noticed that all countries faced serious fluctuations of the external debt in the observed period. Bulgaria for example started its transition period with a ratio of external debt to GDP of over $120 \%$ (Buiter \& Lago, 2001). Bulgarian government declared unilaterally a moratorium on external debt repayment at the beginning of transition, consequently putting country out of the international market (Mihov, 1999). After economic collapse in 1997, total foreign debt that was mainly coming from government borrowing declined from 100\% of GDP in 1997 to less than 60\% in 2003 (Ognivtsev, 2005). As a result of recent financial crisis, Bulgarian external debt rose amounting to 95.9\% of GDP in 2013, mainly due to private sector external exposure. When considering external debt to GDP, Hungary is the most indebted country. As a result of debt accumulation in the communist period, Hungary had unfavourable starting position. For that reason, policy makers decided to lead outward oriented economic transition (Pogátsa, 2009). After the period of late 1990s and early 2000s, when huge capital inflows were obtained through privatization and country recorded strong and stable economic growth, in the light of economic crisis Hungary started to run high budget deficits and now is facing the highest external debt exposure in the public sector together with Serbia and Croatia.

For the most of the observed countries, private sector is financed by the bank loans as a main form of external borrowing. Public sector on the other hand borrows differently which mainly depends on the level of development of financial markets. For example, due to undeveloped domestic bond market, Bosnia and Herzegovina and Albania mainly borrow through external loans (International Monetary Fund, 2014a).

In this chapter, the authors aimed to investigate on which principles Central and Eastern European countries based their policy of providing financial resources from abroad. Within the analysis, it has been examined whether external debt is a consequence of public or private sector external debt rise. In the Background section, a breakdown of current literature on external debt impact on economic growth, 
turning points and thresholds are given. It also provides summary of main findings of the authors that studied external debt sustainability in transition economies. Additionally, methodology concepts and data sources used in the analysis have been presented. The main chapter section is focused on major trends of economic development of selected transition countries. It summarizes obstacles and macroeconomic challenges they faced during the first phase of transition in the 1990s. Solutions and Recommendations and Future Research Directions sections present authors' findings in terms of external debt sustainability indicators, trends, current status and future prospects for each observed country. Finally, in the Conclusion the authors summarized the most important findings and recommendations.

\section{BACKGROUND}

There have been various arguments that economic theory has offered so far in order to explain why the transition countries relied on foreign capital to such a great extent. The basic idea of providing additional financial resources in the foreign markets is to enable investments, which could ensure long term and sustainable economic development. External capital inflow might have multiplicative effects on investments and economic activity influencing further favourable selection of more profitable projects. The projects have been afterwards funded by domestic capital, which resulted with the increase of output per capita (Manzocchi, 1997). The countries where marginal productivity is relatively high, which means the capital is a scarce production factor in those countries, are especially stressed with benefits of external debt (Uzun, Karakoy, Kabadayi, \& Emsen, 2012). Poverty is also perceived as one of important factors of rising indebtedness. In the context of external debt analysis, poverty is related to the external account imbalance since in heavily indebted countries there is a rising gap between national savings and domestic investments (Tiruneh, 2004). Another reason could be the fact that for the growth purposes, a country requires new technology and capital goods. Therefore, export earnings are not sufficient to finance these important growth factors, while domestic capital market is still not developed enough. The role of the government is certainly crucial when it comes to the dynamic of external indebtedness. The accumulation of large external debt is the by-product of government deficit (Lin, 2014). When analyzing external debt accumulation of the Commonwealth of Independent States (CIS-7), Helbling and associates argued that debt accumulation was by product of having continuous large current account deficits and slow economic recovery after the initial slowdown in the first transition years (Helbling, Mody, \& Sahay, 2004).

Many authors analyzed external debt sustainability and tried to determine the level of debt, usually measured by the share of debt in GDP, which results in growth deterioration and has harmful effect on country's ability to repay its obligations. Reinhart and Rogoff (2010) analyzed economic growth and inflation at a different level of government and external debt. In a dataset of 44 countries and a time span of 200 years, they concluded that when a gross external debt reaches $60 \%$ of GDP, annual growth declines by about two percent. As countries hit maximum debt tolerance, there is a pressure on market interest rates to rise which results in painful adjustment (Reinhart \& Rogoff, 2010). They conclude that emerging market growth seems to be particularly hit by the high level of debt to GDP ratio.

In a data set of 93 developing countries observed in the period 1967-1998, Pattillo and associates found nonlinear effects of debt on growth (Pattillo, Poirson, \& Ricci, 2002). Obtained thresholds are debt levels around 160-170\% of exports and 35-40\% of GDP. After these threshold levels further debt accumulation starts to have negative impact. As the authors argued, the marginal impact of debt becomes negative at much lower debt levels, while accurate estimation of the turning is difficult and depends 
on the specific characteristics of the observed country (Pattillo et al., 2002). This is mainly in line with the results obtained by other authors as well. Developed institution is also important factor influencing easier access to private capital. Debt overhang for countries with developed institutional framework is $15-30 \%$ of GDP. Countries with worse institutional conditions seem to exhibit a similar pattern but with significantly lower thresholds. Related thresholds are between $0 \%$ and $20 \%$ of GDP (Cordella, Ricci, \& Ruiz Arranz, 2010). Similarly, Calvo and associates found quadratic relationship between external debt and growth (Calvo, Stefanoudakis, \& Blanco Tames, 2009). They argued that reasonable level of debt stimulates growth to a certain point, while excessive level is proved to have harmful effects on growth. In a sample of 30 randomly chosen developing countries over a period of 33 years (1970-2003), they found that optimal level of external debt to GDP ratio is 54\% (Calvo et al., 2009).

Unlike the previous authors, Schclarek (2004) did not find enough evidence to support a nonlinear relationship, while no evidence at all for positive relationship between total external debt and growth at low debt levels. As for developing countries, the results are dramatically different. Total external debt has significant adverse impact on economic growth. When considering specific components of debt, a negative relationship between public external debt and growth has been shown, while no significant relationship has been detected concerning private external debt impact (Schclarek, 2004).

By taking into consideration other important variables affecting growth, there were findings proving corruption, as a measure of institutional quality which is highly relevant for debt-growth relationship. In countries with lower levels of corruption both the positive and negative effects of debt on growth, modelled with a non-linear debt specification, are significant. In countries with higher levels of corruption, only the negative effects of debt on growth could be detected. Corresponding turning points for debt levels are between $21 \%$ and 30\% of GDP for highly corrupted countries and 31-45\% for countries with lower level of corruption. In other words, countries with lower level of corruption may incur higher external debt to support their growth (Jalles, 2011).

Most of the performed research aimed to give an answer on external debt sustainability issues of highly indebted poor countries (HIPC). However, recent economic crisis brought attention to the EU and especially EU periphery countries as well as potential EU members. Arguments behind this sudden interest could certainly be increased public debt and high budget deficits led by these countries. In the EU countries, particular importance is given to the analysis of net external debt. Since EU members hold significant amount of foreign receivables, net external debt positions need to be taken into account. Comprehensive evaluation of external macroeconomic imbalance should also include international investment position (IIP) and net external debt. According to Cuestas and associates, most of the EU countries successfully managed to control the way they accumulate their debt (Cuestas, Gil-Alana, \& Regis, 2014). The analysis performed in order to capture the reaction of present debt accumulation to past debt stock found structural breaks in most cases after 2008. This is explained by the government policy measures. Results have shown that only Croatia, Finland, Germany, Ireland, and Poland did not put their debt under control (Cuestas et al., 2014). However, there were no authors trying to refute the already accepted thesis that growth and macroeconomic stability are to high extent influenced by external debt. It is not the debts (public and external) that are in general dangerous for growth, but instead the dangers may arise at high values of indebtedness (Simic \& Mustra, 2012).

Research performed in order to particularly analyze external sustainability in transition countries mainly relied on the IMF and the World Bank analysis framework and relevant stock and flow indicators. Josic (2013) found Croatia and Serbia to be the most vulnerable economies in the region when considering five indicators of external debt sustainability, particularly Debt to GDP, Exports to GDP and Debt service to 
GDP. Similar analysis of the sustainability indicators in Romania has shown that all indicators worsened particularly during the crisis period (2009-2011), while both medium and long-term external debt rose in absolute and relative figures. Since internal resources were considered to be insufficient, credits were taken from international institutions. Rise of external debt has not been followed by economic growth. On the contrary, external debt has not been used for profit yielding, productive purposes, for generating economic growth and the increase of the gross domestic product, but for other purposes, among which non-productive consumption (Milea, 2014). Similar conclusions have been obtained in other research that covered the observed countries. Vlahnic Dizdarevic and associates argue that despite the increase of foreign debt in South-East Europe, maturity composition is favorable since all countries have high share of long-term debt in total debt, with Bulgaria as the only exception (Vlahinic Dizdarevic, Buterin, \& Zagar, 2006). Bunda (2013) on the other hand warns that gross external financing needs of Hungary, defined as current account deficit plus amortization on medium and long-term debt plus short-term debt at the end of previous period as well as the short-term debt, are high when reserves coverage is considered. External sustainability in Serbia has also been a subject of research performed by Boljanovic (2013), who claimed that current account deficit in Serbia is above the sustainable level, and the most vulnerable point when compared to other South-East European countries. Finally, common logic might be questionable when it comes to relation between success in transition and external debt accumulation. On a sample of 27 transition countries, Filipovic and associates have proved that countries with higher average transition indicators have also had a higher level of indebtedness (Filipovic, Raspopovic, \& Toskovic, 2015).

The most widely used methodology of external debt sustainability is given by the International Monetary Fund (IMF) - External debt statistics for compilers and users. It provides theoretical and analytical framework for assessing external position of a country. In the context of debt sustainability, the IMF has developed conceptual framework for measurement of external debt and its components including sustainability indicators (International Monetary Fund, 2014b). Basically, there are two approaches when measuring external debt sustainability (Arnone, Bandiera, \& Presbitero, 2005):

- Financial sustainability approach based on the analysis of financial possibilities for future debt increase;

- Economic sustainability approach based on the analysis of different economic variables and running different scenarios on external debt future behaviour.

In this chapter, the authors adopted basic concepts of debt assessment given by the IMF with a particular focus on financial sustainability perspectives. Financial sustainability indicators include assessment of liquidity and solvency of a particular country. Authors' analysis is mainly focused on stock-based debt burden indicators such as debt-to-export ratio and debt-to-GDP ratio.

The basis equation is:

Debt indicator $=$ Indebtedness / Repayment Capacity (1)

In order to measure indebtedness, the authors used gross external debt as a debt stock. Gross external debt is the outstanding amount of those actual current, and not contingent, liabilities that require payment(s) of principal and/or interest by the debtor at some point(s) in the future and that are owed to non-residents by residents of an economy (International Monetary Fund, 2011). In addition, the authors 
aimed to analyze whether external debt trends are mainly influenced by the government or private sector. For countries in which public sector is responsible for a large share of the external debt, it is particularly important to identify all the debt owed to non-residents by this sector (International Monetary Fund, 2014b).

Repayment capacity is mainly analyzed through GDP, exports and government revenues. While GDP captures all resources of the economy, exports show ability of a country to collect foreign currency, which is necessary for debt repayment. Debt repayment capacity could be also analyzed through government revenues since tax payers are those who provide funds to pay out obligations.

Flow-based indicators are also important in order to obtain information on debt sustainability. In this chapter, the authors used flow-based indicators and forward looking analysis provided by the European Commission reports, complementary to the stock-based measures. Special focus of the chapter is to analyse evolution of the external debt in the selected eight transition countries trying to capture the main drivers of the external debt rise. Therefore, the authors were mainly focused on solvency rather than liquidity issues.

The chapter is based on a long-term analysis of the examined phenomena, including time series and space comparisons. Additional method that the authors used is a synthesis of the previously obtained results. For the purpose of the research data from national and international institutions are used, mainly web sources of the relevant national banks, the IMF, the World Bank, and Eurostat.

\section{MAIN FOCUS OF THE CHAPTER}

After the fall of communist regimes, consequences of the first transition measures were high inflation, substantial fall in real GDP, rise in unemployment, and worsening of other social indicators (Uvalic, 2010). In the following years, macroeconomic indicators signalled slow but fragile economic recovery that was usually followed by current account deterioration since trade liberalization resulted in disproportionate rise of imports. Strong and steady GDP growth was recorded in Slovenia, Hungary and to some extent in Croatia (Table 1). Other countries grew slowly or with observable structural breaks resulting from internal or external shocks mainly due to political instability and inconsistent reform processes.

Table 1. Annual percentages of constant price GDP year-to-year growth, \%

\begin{tabular}{|l|c|c|c|c|c|c|c|}
\hline \multicolumn{1}{|c|}{ Country/Year } & $\mathbf{1 9 9 4}$ & $\mathbf{1 9 9 5}$ & $\mathbf{1 9 9 6}$ & $\mathbf{1 9 9 7}$ & $\mathbf{1 9 9 8}$ & $\mathbf{1 9 9 9}$ & $\mathbf{2 0 0 0}$ \\
\hline Bulgaria & -3.67 & -1.60 & -8.04 & -5.84 & 4.12 & 2.28 & 5.39 \\
\hline Croatia & 5.90 & 6.63 & 5.84 & 5.36 & 2.52 & 0.00 & 4.18 \\
\hline Czech Republic & n.a. & n.a. & 4.28 & 0.00 & 0.00 & 1.44 & 4.29 \\
\hline Hungary & 2.95 & 2.54 & 0.00 & 3.37 & 4.21 & 3.24 & 4.24 \\
\hline Romania & 3.93 & 7.14 & 3.95 & -6.05 & -4.82 & -1.15 & 2.92 \\
\hline Slovak Republic & 6.21 & 7.87 & 6.94 & 4.45 & 3.99 & 0.00 & 1.21 \\
\hline Slovenia & 5.30 & 4.10 & 3.60 & 5.11 & 3.29 & 5.28 & 4.16 \\
\hline Serbia & n.a. & n.a. & n.a. & n.a. & n.a. & -11.17 & 5.25 \\
\hline
\end{tabular}

Note: Base year is a country specific

Source: International Monetary Fund (2015a, 2015b) 
Table 2. Current account balance in the period 1994-2000 (in \% of GDP)

\begin{tabular}{|l|c|c|c|c|c|c|c|}
\hline \multicolumn{1}{|c|}{ Country/Year } & $\mathbf{1 9 9 4}$ & $\mathbf{1 9 9 5}$ & $\mathbf{1 9 9 6}$ & $\mathbf{1 9 9 7}$ & $\mathbf{1 9 9 8}$ & $\mathbf{1 9 9 9}$ & $\mathbf{2 0 0 0}$ \\
\hline Bulgaria & -0.38 & -0.19 & 0.15 & 3.89 & -0.46 & -4.74 & -5.25 \\
\hline Croatia & 3.94 & -5.84 & -3.99 & -12.15 & -6.71 & -7.40 & -2.21 \\
\hline Czech Republic & n.a. & -2.34 & -6.26 & -5.79 & -1.93 & -2.27 & -4.45 \\
\hline Hungary & -9.45 & -3.55 & -3.80 & -4.35 & -7.00 & -7.68 & -8.51 \\
\hline Romania & -1.66 & -4.45 & -6.63 & -5.39 & -6.84 & -4.05 & -2.59 \\
\hline Slovak Republic & 4.19 & 2.74 & -9.69 & -8.84 & -9.58 & -4.42 & -3.03 \\
\hline Slovenia & 4.17 & -1.45 & 0.09 & 0.14 & -0.86 & -4.01 & -3.23 \\
\hline Average & 0.14 & -2.15 & -4.30 & -4.64 & -4.77 & -4.94 & -4.18 \\
\hline
\end{tabular}

Source: International Monetary Fund (2015a, 2015b)

All countries had serious current account imbalances, which was a natural consequence of trade liberalization. The highest deficits were recorded in Hungary, Bulgaria, and Czech Republic (Table 2). Rising current account deficits were also present in the first decade of the 21 st century. The peak was in 2008, when Serbia and Bulgaria recorded current account deficit amounting to $21.0 \%$ and $22.4 \%$ of GDP consequently.

Another important characteristic of the transition period was attraction of foreign direct investments. As an important source of capital, FDI have always been considered valuable for transition economies. The best performers in terms of FDI attraction and export growth were the Czech Republic and Hungary, and later Slovakia (Table 3). In the period 1995-2000, total FDI inflow in the Czech Republic was around $\$ 18.5$ billion, six times higher than in Bulgaria and four times higher than in Croatia. Extremely low inflow of FDI was recorded in Serbia and Slovenia.

In terms of external debt, trends were also quite diverse. Czechoslovakia led prudent fiscal policy during the communist period and consequently, Slovakia and the Czech Republic had almost no debts in the light of transition reforms (Buiter \& Lago, 2001). Both Romania and former Czechoslovakia sped up debt accumulation processes in the beginning of the 1990s. However, the Czech Republic and Slovakia accumulated official reserves as well, while Romania did it very slowly. Therefore, net foreign

Table 3. FDI inflows by host region and economy, \$ million

\begin{tabular}{|l|c|c|c|c|c|c|}
\hline \multicolumn{1}{|c|}{ Country/Year } & $\mathbf{1 9 9 5}$ & $\mathbf{1 9 9 6}$ & $\mathbf{1 9 9 7}$ & $\mathbf{1 9 9 8}$ & $\mathbf{1 9 9 9}$ & $\mathbf{2 0 0 0}$ \\
\hline Bulgaria & 90 & 109 & 505 & 537 & 819 & 1,002 \\
\hline Croatia & 114 & 511 & 540 & 935 & 1,474 & 899 \\
\hline Czech Republic & 2,562 & 1,428 & 13 & 3,718 & 6,324 & 4,595 \\
\hline Hungary & 4,453 & 2,275 & 2,173 & 2,036 & 1,944 & 1,957 \\
\hline Romania & 420 & 265 & 1,215 & 2,031 & 1,041 & 998 \\
\hline Slovak Republic & 195 & 251 & 206 & 631 & 356 & 2,075 \\
\hline Slovenia & 176 & 186 & 321 & 165 & 181 & 181 \\
\hline Serbia and Montenegro & 45 & 102 & 740 & 113 & 124 & 29 \\
\hline
\end{tabular}

Source: United Nations Conference on Trade and Development, 2001 
debt situation in these countries was dramatically different (Manzocchi, 1997). Slovenia inherited part of Yugoslav debt, but resulting from quick rise of exports and prudent macroeconomic policy it used to be the least indebted transition country in 2000, with an external debt-to-GDP ratio of about 30\% (Buiter \& Lago, 2001). Since 1992, it started to accumulate reserves. Due to a significant rise of public debt, Slovenia is now everything but an example of good practice. Only debt servicing in Slovenia exceeds more than $10 \%$ of GDP.

Serbia and Croatia experienced delay in transition resulting from the war environment. Croatian debt had a steady rise during the 1990s. It used to be close to $85 \%$ of GDP at the end of 2003, and the trend was assessed to be unsustainable. In the period 1998-2003, debt to GDP and to exports had been growing by 8 percentage points in average (Gligorov, 2004). Finally, Serbia is a rather specific example and for many indicators there are no official and reliable data covering the period of early 1990s. During the 1990s, relations with international financial institutions were blocked. At the end of 2001, after the political changes, Serbian starting point in terms of gross external indebtedness was $74.6 \%$ of GDP. In 2002 and 2003, large part of debt was written off as a result of negotiations with Paris and London Clubs of creditors. Relatively stable GDP growth in the forthcoming years influenced sustainability indicators to be on relatively moderate levels. Debt rise was primarily a consequence of credits took by private sector. Recent economic crisis discovered structural problems of Serbian economy. The rise of external debt is in strict correlation with the rise of public debt.

Aforementioned indicators of transition reforms, GDP growth, value of exports, current account balance, and FDI inflows are not correlated with the level of external debt. Countries that recorded GDP growth and significant FDI inflow have also accumulated a large amount of external debt measured by share in GDP such as Hungary. On the other hand, there were countries, such as Romania, that although achieving relatively modest transition results measured by the macroeconomic indicators, had relatively low level of external debt to GDP. This is partly in line with the findings obtained by Filipovic and associates (Filipovic et al., 2015). However, there were countries such as the Czech Republic, which proved to be the top performer showing success in transition reforms but also had satisfying external sustainability indicators and reasonable share of external debt.

External debt accumulation is considered to be typical for countries in transition to market-based economy. Capital inflows in those countries are required since domestic financial resources are not high enough to support consumption, investments and economic growth in general, especially during the initial phase of transition. However, observed transition countries continued to accumulate their debt afterwards, which is in line with general trend in the EU. In this research, the main focus is on the gross external debt indicator, as it is a more relevant concept in a crisis situation when government and private agents have to service and roll over their debt obligations. In addition, foreign assets may also be harder to access immediately (Gros \& Alcidi, 2011). Gross external debt of the advanced economies recorded significant rise in the 2000s and was followed by the economic growth as well (Figure 1). As expected, the rising trend continued during the crisis period in response to the government's needs for financial resources. In absolute figures, the most dynamic rise of gross external debt was recorded in Hungary and Czech Republic. Other observed countries followed similar pattern. Slovakia experienced very sharp external debt rise in the crisis period. Similar, but a little bit slower, the rising trend was recorded in Slovenia, Croatia, and Serbia.

If country's GDP is used as an approximation of debt repayment capacity, it could be noticed that external debt rise in the selected transition countries was followed by the dynamic rise of GDP. In the pre-crisis period, debt share in GDP dramatically increased in all the observed countries (Figure 2). 
Figure 1. Gross external debt (in € million, period 1999-2013)

Source: International Monetary Fund (2015a, 2015b); Bank of Slovenia (2015); Croatian National Bank (2015); Czech National Bank (2015); Hungarian National Bank (2015); National Bank of Bulgaria (2015); National Bank of Romania (2015); National Bank of Serbia (2015b); National Bank of Slovakia (2015)

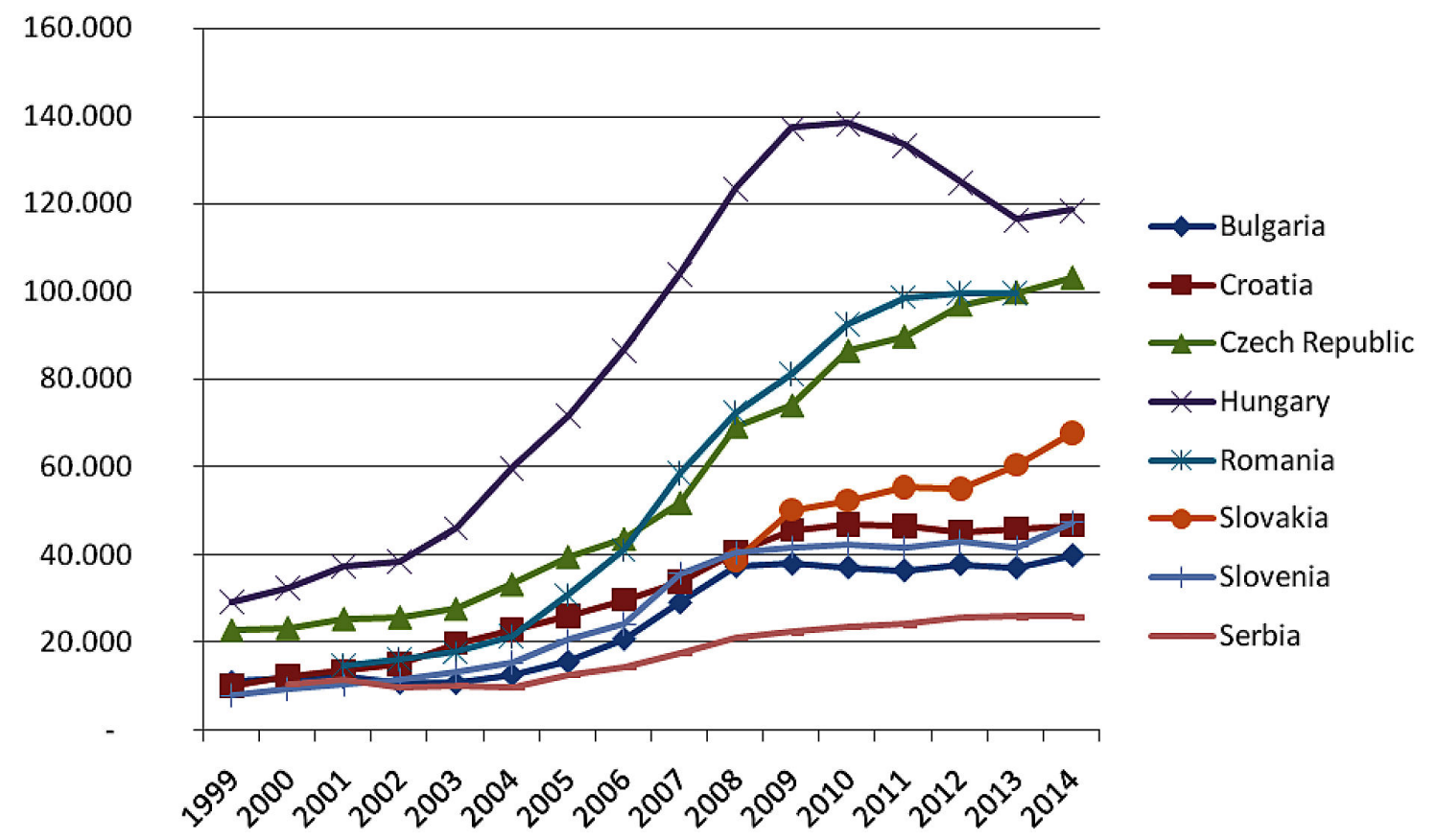

However, during and after the crisis period, the ratio of gross external debt in GDP had divergent trends in the observed economies. While Hungary experienced a sharp rise of gross external debt, which rose up to $147 \%$ of GDP in 2009 , the analyzed ratio started to decrease in the last couple of years, amounting to $115 \%$ in 2014 . Similar pattern was recorded in Romania, although the debt share was at much lower levels. Most of the countries faced stagnation in terms of the aforementioned indicator as the first crisis shock passed. This trend has been observed in Croatia, Serbia, and Bulgaria. Debt increase has never stopped in Slovenia, Slovakia, and the Czech Republic.

When compared to the explanations given by other authors, it is a common attitude that values for the most of the countries are within the range, which indicates that potential harmful effects of debt to growth and economic stability might exist. Although there is no accepted threshold for the gross external debt to GDP ratio, especially for middle and high income countries, findings obtained for the developing countries indicate that average impact of external debt to GDP becomes negative at $35-40 \%$ of GDP (Pattillo et al., 2002), or 15-30\% of GDP (Cordella et al., 2010). At least, the authors could say that for those countries a negative relationship exists, whether it is U inverted non-linear or linear as suggested by Schclarek (2004). Slovenia, Hungary, and Croatia have the worst value of this indicator, all above $100 \%$ of GDP, with a ratio of $126 \%, 115 \%$, and $108 \%$ respectively.

Another important aspect of external debt sustainability is the debtor structure. It is particularly important to distinguish whether the debt rise is a consequence of the emerging public or private debt (Figure 3). The negative relationship between debt and growth is proved to be significant for the incidence of public external debt level (Schclarek, 2004). 
Figure 2. Gross external debt share in GDP (in \%, period 2003-2014)

Source: Authors' own calculation based on Bank of Slovenia (2015); Croatian National Bank (2015); Czech National Bank (2015); Hungarian National Bank (2015); National Bank of Bulgaria (2015); National Bank of Romania (2015); National Bank of Serbia (2015b); National Bank of Slovakia (2015); Eurostat (2015a, 2015b)

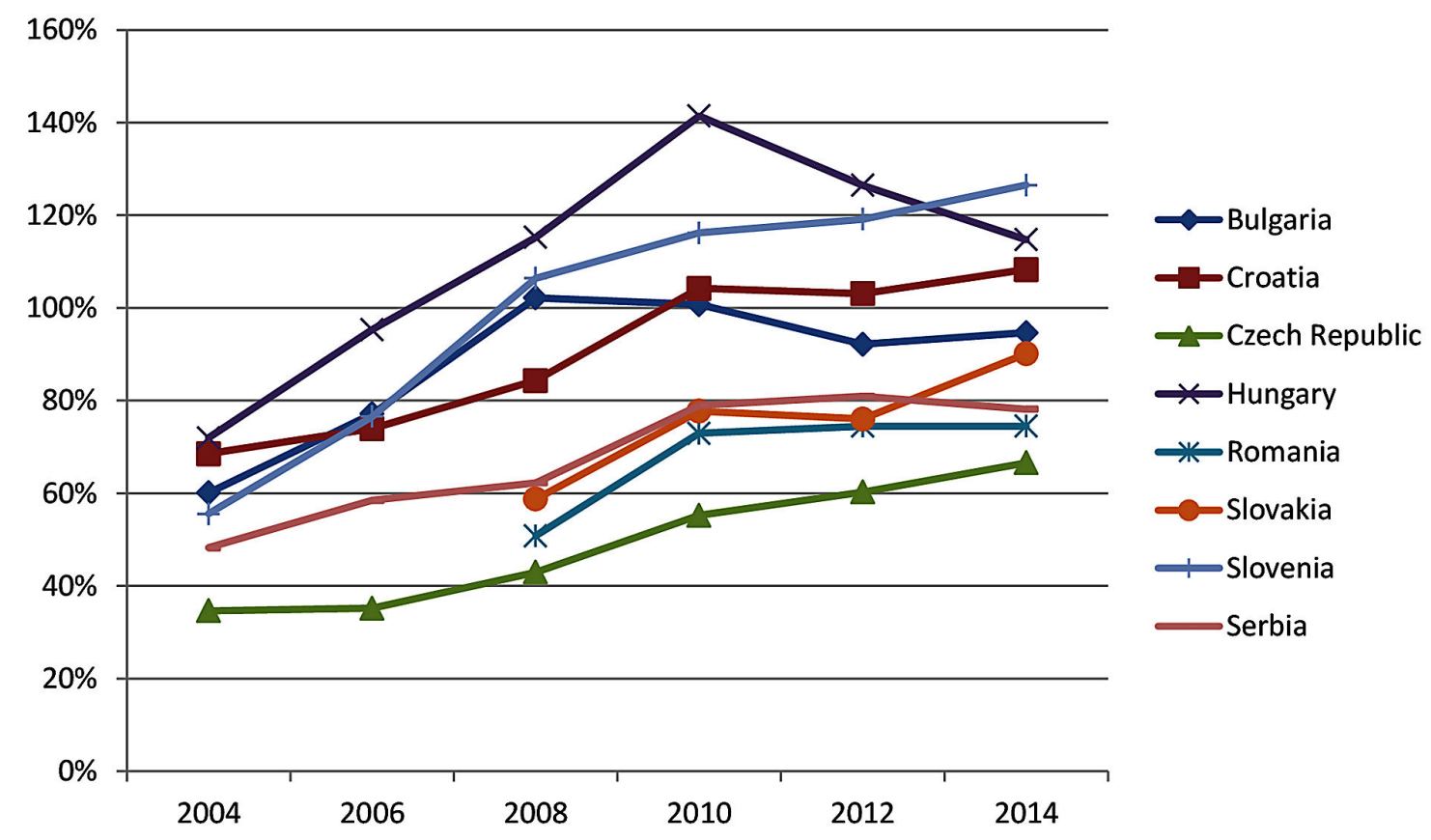

Figure 3. Public external debt share in GDP (in \%, period 2003-2014)

Source: Authors' own calculation based on Bank of Slovenia (2015); Croatian National Bank (2015); Czech National Bank (2015); Hungarian National Bank (2015); National Bank of Bulgaria (2015); National Bank of Romania (2015); National Bank of Serbia (2015b); National Bank of Slovakia (2015); Eurostat (2015a, 2015b)

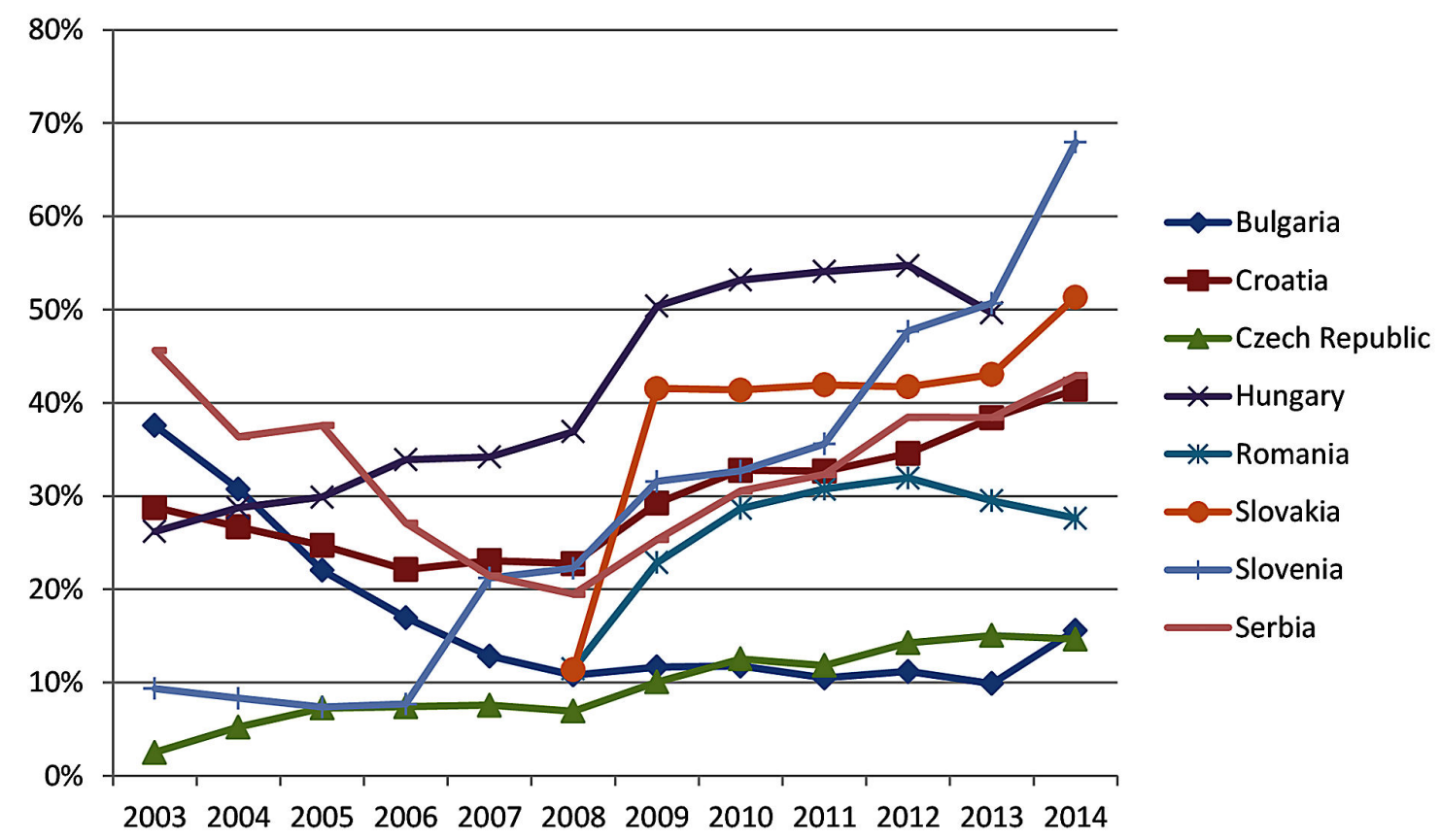


In short, public external debt refers to the debt owed by the government, central bank, and publicly guaranteed debt of the private sector. Contrary to the gross external debt, its public debt component had quite a different trend in the observed period. It did not record a significant rise in the beginning of the first decade of the 21st century, but only in the period of the crisis. Accumulation which started in the crisis period was driven by lower fiscal revenues and related budget deficits. Consequently, the selected transition countries almost doubled the share of the external public debt in 2014 comparing to 2008. Regarding current tendencies, the sharpest increase was recorded in Slovenia (68\% of GDP in 2014), Serbia (43\%), and Croatia (41\%).

Since the largest portion of the external debt in those countries is the debt denominated in foreign currency, it is particularly important to analyze export as an indicator of repayment potential (Figure 4). That is due to the fact that the debt denominated in foreign currency needs to be financed in foreign exchange which could be collected through export and remittances, while the government collects revenues in domestic currency. According to the debt sustainability indicators developed within the Heavily Indebted Poor Countries Capacity Building Programme, the threshold for the external debt to export of goods and services is set to be $150 \%$. Moderately indebted countries have present external debt to export value in the range between 132\% and 220\% GDP (Development Finance International, 2009).

According to the performed calculation, the highest share of external debt to export was recorded in Croatia, Serbia, and Romania amounting to $237 \%, 176 \%$, and around $170 \%$ respectively. However, recent trends indicate that ratio has slowly decreased in the last two years. In addition to Croatia, Romania, and Serbia, only Slovenia exceeds the threshold of $150 \%$. Strong and relative stable export values in Slovakia and the Czech Republic during the whole transition period ensured these countries to have

Figure 4. Gross external debt to exports of goods and services (in \%, period 2003-2014) Source: Authors' own calculation based on Bank of Slovenia (2015); Croatian National Bank (2015); Czech National Bank (2015); Hungarian National Bank (2015); National Bank of Bulgaria (2015); National Bank of Romania (2015); National Bank of Serbia (2015b); National Bank of Slovakia (2015); Eurostat (2015a, 2015b)

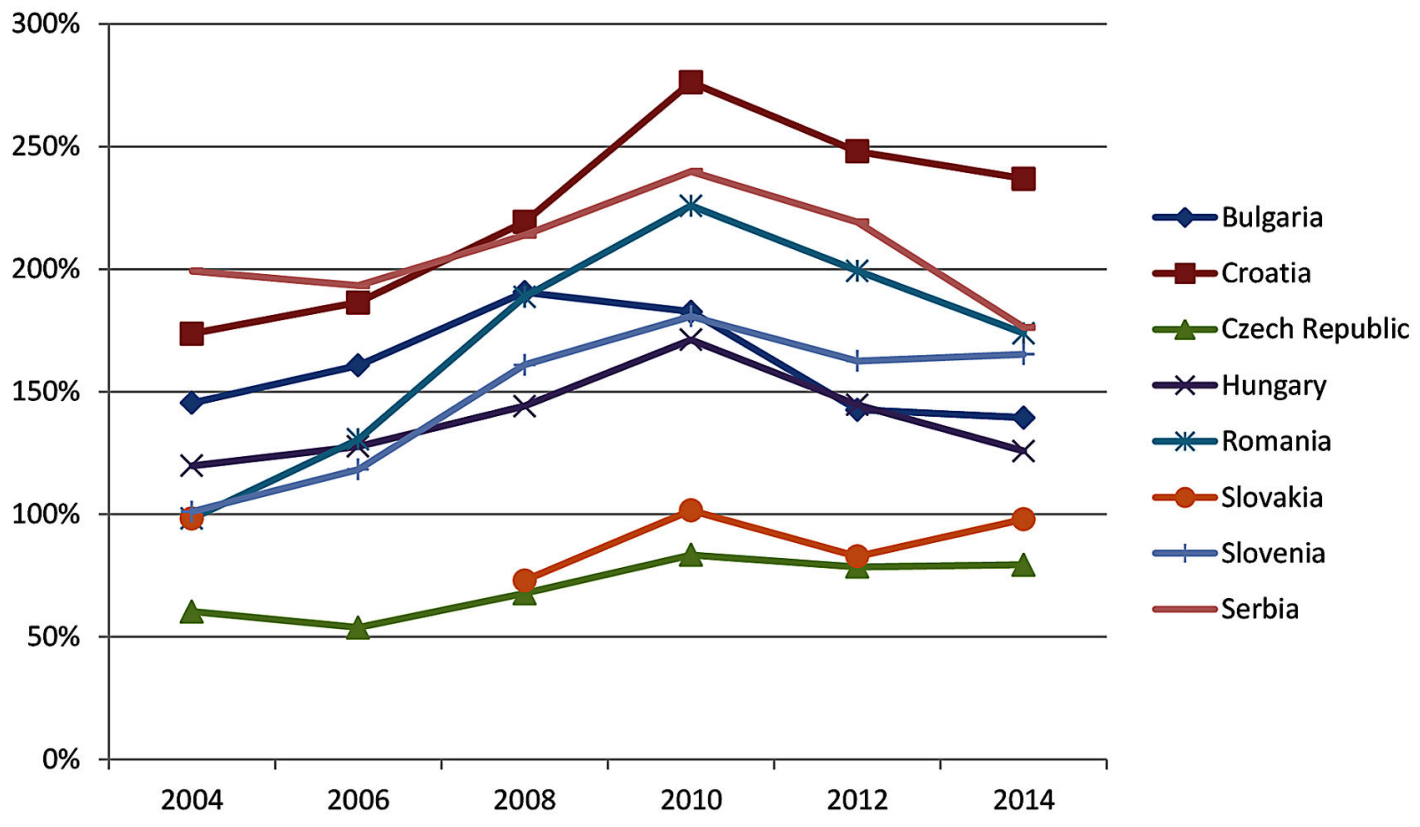


Implications of Globalization on Growing External Debt in Eight Transition Economies

relatively low values of the analyzed indicator. As an illustration, Slovakia export is worth around $€ 70$ billion and $90 \%$ of GDP in 2014, which is twice higher share of export comparing to Serbia or Croatia indicating openness of the Slovak market but also sustainable external position of the Slovak economy.

\section{SOLUTIONS AND RECOMMENDATIONS}

In addition to the common debt burden indicators, there are also other indicators developed to help in assessing external vulnerability of a particular country. In their analysis, the authors used Net International Investment Position (NIIP) as the value of foreign assets owned by the public and private sector. It is a sum of past current account deficits or surpluses. The use of this indicator is usually justified by the fact that it is the broadest measure of the net external balance. It could be used as a benchmark since external debt burden indicators could exaggerate or underestimate external vulnerability, which has been shown in the example of Ireland (Creedon, Fitzpatrick, \& Gaffney, 2012). In that context, it should be noticed that most of the observed economies do not belong to the euro area, which brings specific type of risk itself for further analysis. Key difference between the countries in the Eurozone and other EU countries is that Eurozone members may account for the European Central Bank (ECB) support in terms of refinancing and delaying necessary external adjustment.

\section{Bulgaria}

Bulgarian external position seems relatively stable comparing to other transition countries. Gross external debt amounting to $95 \%$ of GDP is significant, but mainly concentrated in the private sector, resulting from intercompany lending. Public and publicly guaranteed external debt portion in GDP is around $16 \%$, which is quite low, especially when compared to similar countries (Figure 5). Net external debt to GDP ratio in 2013 was around 37\% of GDP, referring to quite high amount of external assets that were estimated to be around $€ 22.5$ billion in 2013 (European Commission, 2015a). In terms of liquidity, gross debt service takes a large share of GDP. The examined data suggest that public sector debt service represents only a small portion of gross debt service, which is strong evidence that risks concerning external illiquidity are relatively small. Debt repayment of the private sector in recent years and relatively stable current account situation should enforce the external position of a country. Potential risks in the future could only be affected through an unexpected rise of the government budget deficit in the future (National Bank of Bulgaria, 2014).

The external position measured by NIIP is highly negative amounting to $77 \%$ of GDP (Figure 6). However, in addition to the current account stability, the most important issue will be how to ensure that government deficit need is under control.

\section{Croatia}

One of the main problems of Croatian economy is a steep upward trend of the public debt. The external component is also quite high comparing to other observed countries. The total public debt ratio in GDP is above $80 \%$ of GDP (Figure 7), while gross external debt amounted to $108 \%$ in 2014. Public and publicly guaranteed external debt is more than $40 \%$ of GDP. Such a high debt stock in a small open economy is also affecting private borrowing costs, reducing investments and creating a drag on the economic recovery (European Commission, 2015b). Solely net external debt amounts to 60\% of GDP. 
Figure 5. Gross external debt service in the period 2002-2013 (\% in GDP) Source: National Bank of Bulgaria, 2014

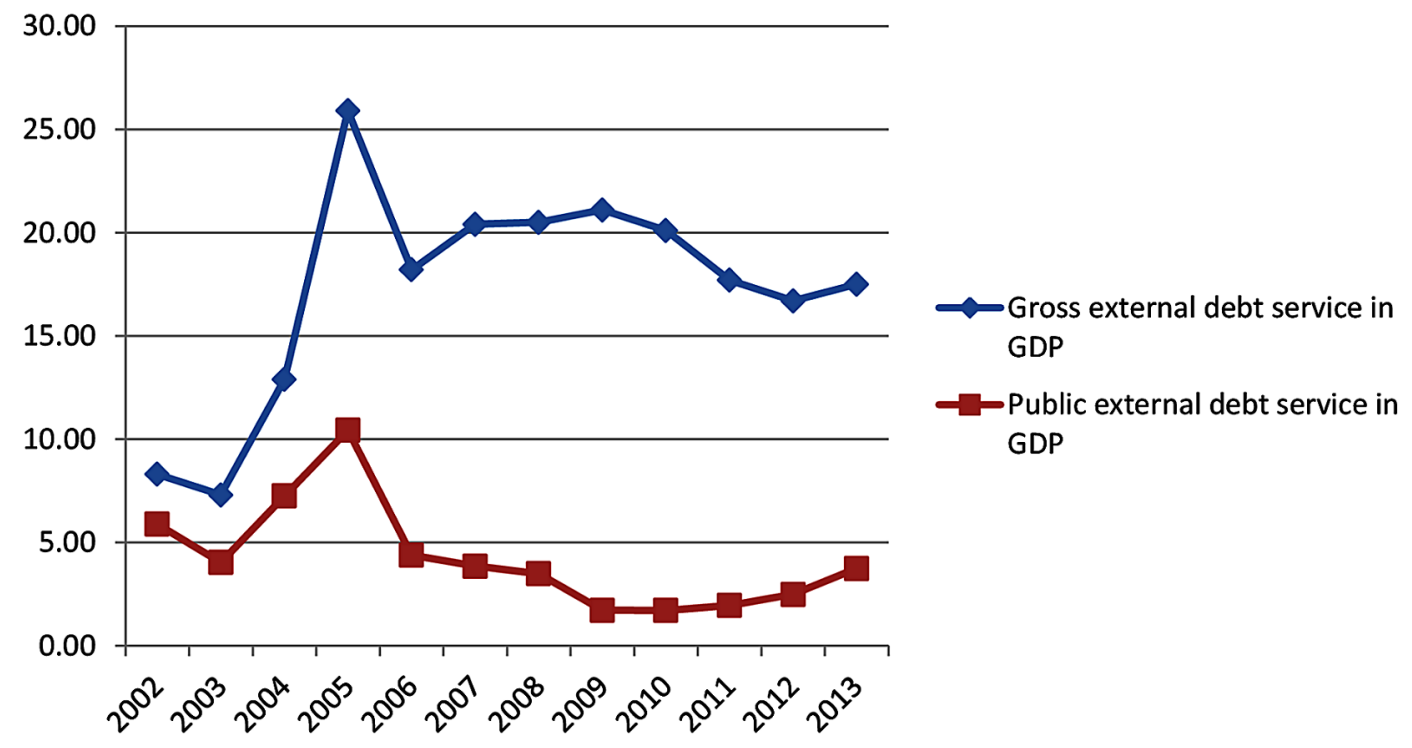

Figure 6. NIIP of Bulgaria in the period 2008-2013 (in \% of GDP) Source: European Commission, 2015 a

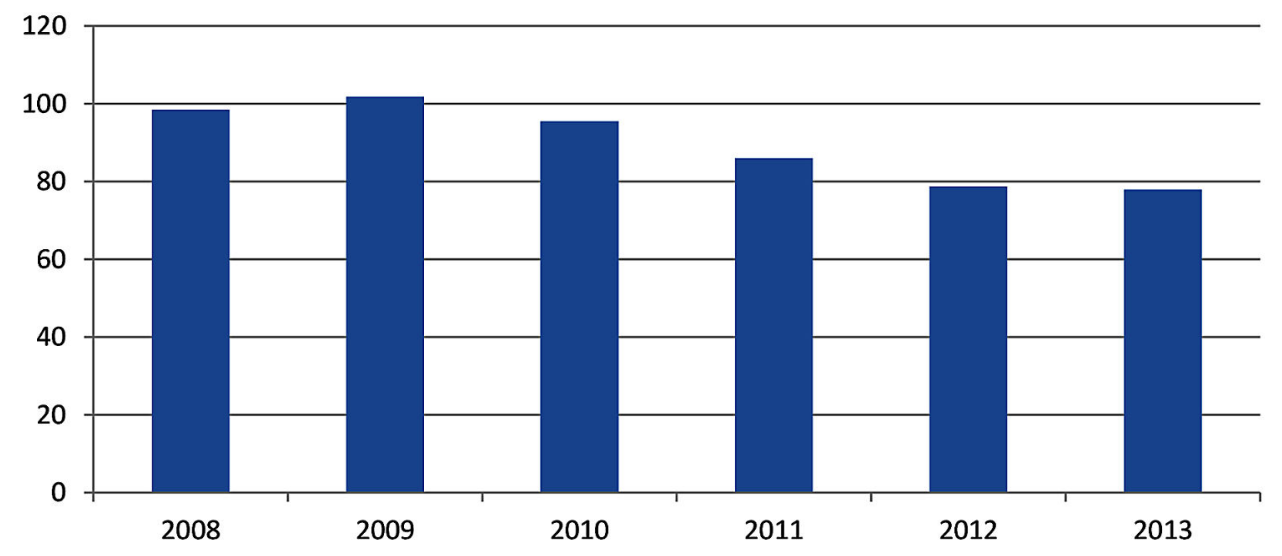

In addition, NIIP was seriously jeopardized (Figure 8). Current situation indicates that the country will need to enhance its export revenues and FDI inflow in order to stabilize external position.

\section{Czech Republic}

Despite of upward and stable trend of increase after 2008, external debt share in GDP is still relatively low and amounted around $67 \%$ of GDP. Almost $60 \%$ of that debt is debt of the private sector. External position in general could be assessed as very good. With the exception of 2009, export has recorded stable and significant rise in the period 2008-2014. This is reflected through continuous surpluses in trade balance. Government led prudent fiscal policy, which resulted in stabilization of general govern- 
Figure 7. General government deficit and general gross government debt in Croatia (in \% of GDP) Source: European Commission, $2015 b$

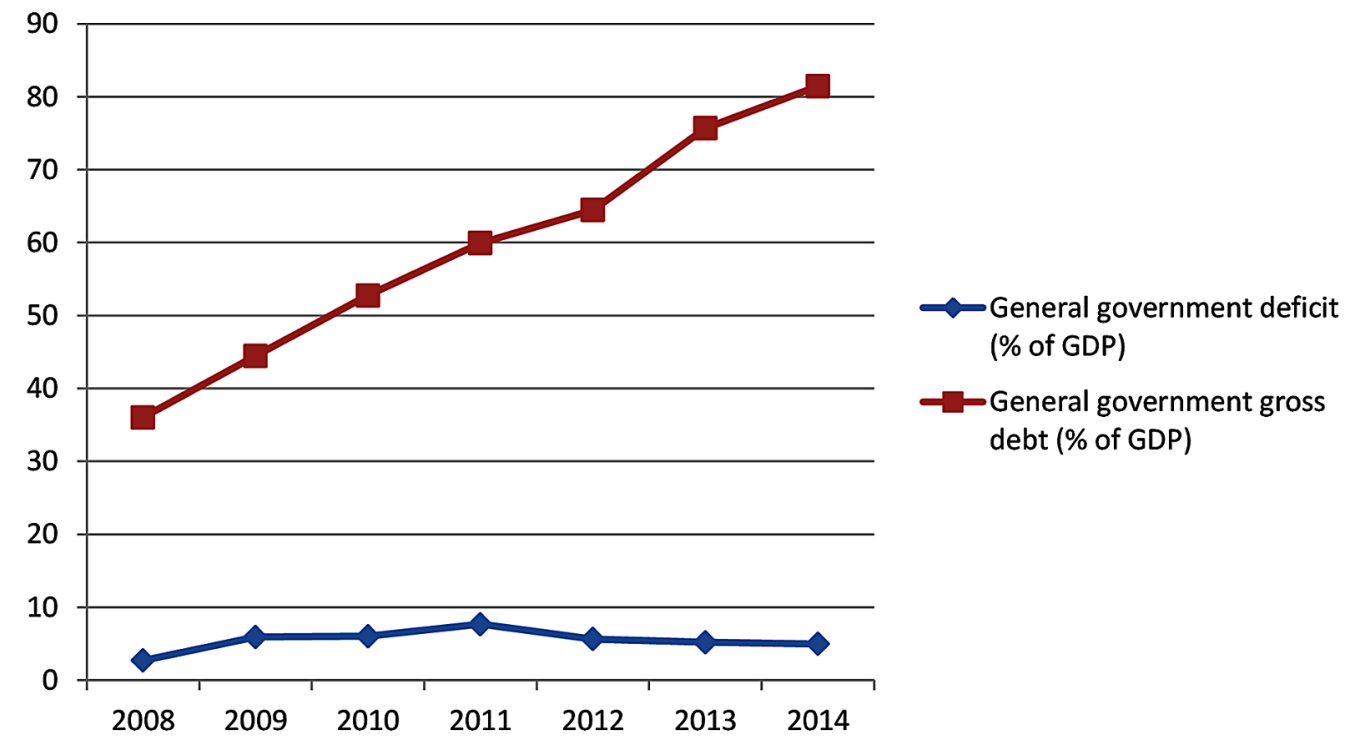

Figure 8. NIIP of Croatia in the period 2008-2013 (in \% of GDP) Source: European Commission, $2015 \mathrm{~b}$

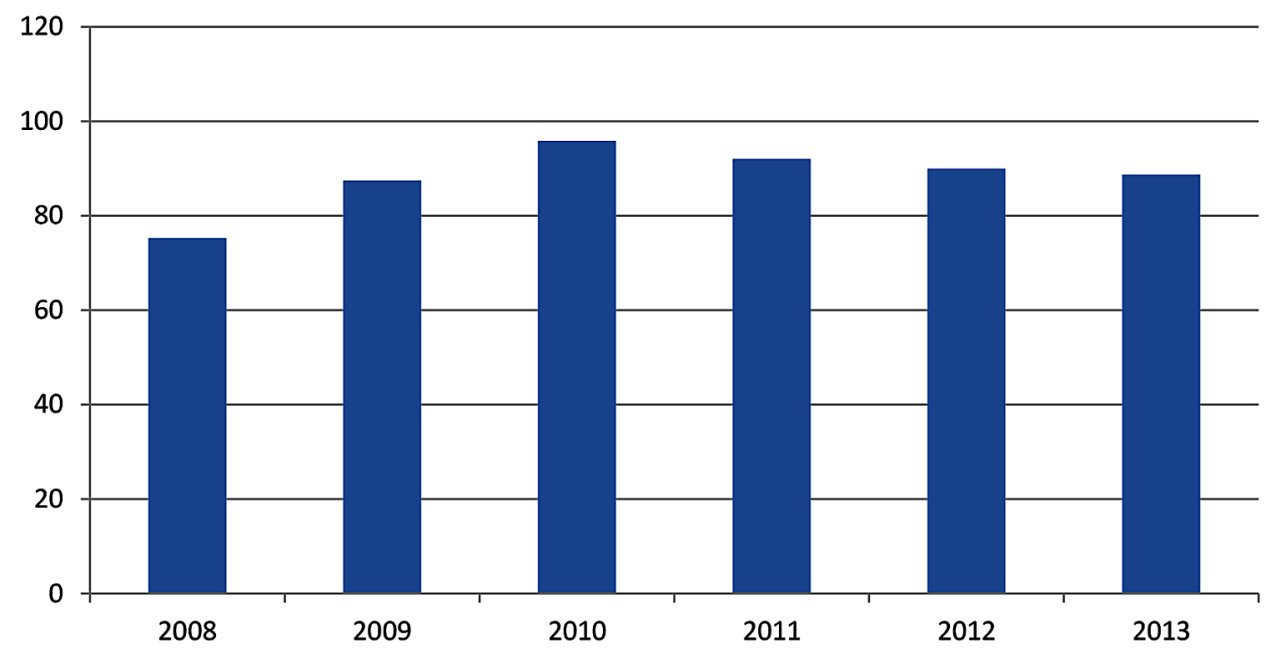

ment balance and stagnation of public debt. Therefore, the Czech Republic in the context of external position seems to be the top performer among the observed countries. This is specifically proved by the remarkable low level of external debt to exports, which amounted 79\% of GDP (European Commission, 2015c). Additionally, net external position is stable and significantly lower when compared to peer countries (Figure 9). 
Figure 9. NIIP of the Czech Republic in the period 2008-2013 (in \% of GDP) Source: European Commission, 2015c

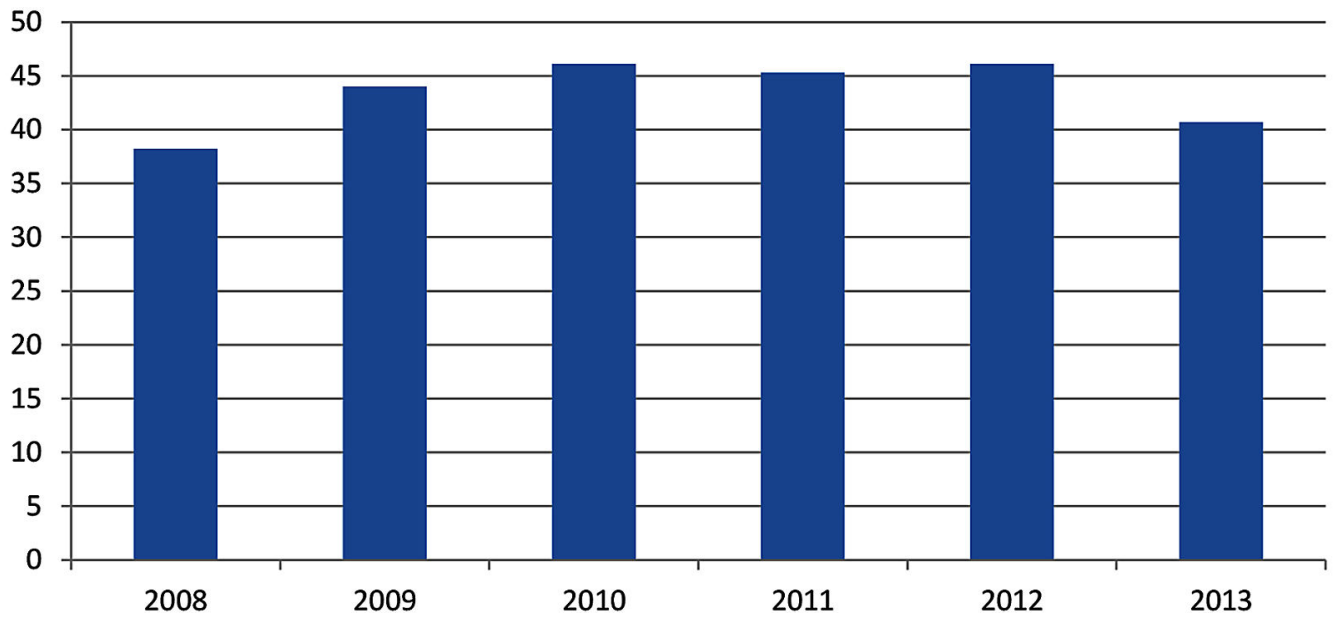

\section{Hungary}

By the share of gross external debt, Hungary is classified as very indebted country. Gross external debt to GDP amounted $116 \%$ in 2013 . On the other hand, stable export is contributing to the overall external stability. Gross external debt to exports ratio was around 126\% and returned to the levels from 2004 and 2005 after a significant rise during the crisis. There is a discrepancy between gross and net external debt, which indicates reasonable amount of financial assets as well. Before the crisis, Hungary was one of the countries with the most dynamic debt accumulation, which was in the first phase of transition influenced by the private sector debt. In the pre-crisis period, and during the crisis, gross external debt sharply increased due to the rise of its public component. As an illustration, Hungarian budget deficit jumped up to $9.3 \%$ of GDP. It was the second highest budget deficit in 2006 after Lebanon (Miklos, 2011). However, in the last five years government debt accumulation has been surpassed by deleveraging processes of the private sector, which influenced stabilization of main indicators.

Recent improvements, external adjustment and high rollover needs have to be carefully monitored by the policy makers in the forthcoming period since negative net internal investment position is still high and represents serious risk for future stability (Figure 10).

\section{Romania}

Romanian external debt position in the last years is satisfying. At the end of 2013, external debt amounted to $69 \%$ of GDP, which is a substantial rise comparing to $55 \%$ in 2008 , but also a solid decrease when compared to 2012. Strong growth of both exports and GDP in the period 2010-2014 influenced improvement in net international investments position (Figure 11). It is encouraging that public component of external debt as well as the total public debt levels are at the lowest among peer countries, which put Romania in a relatively comfortable position in terms of fiscal policy. 
Figure 10. NIIP of Hungary in the period 2008-2013 (in \% of GDP) Source: European Commission, 2015d

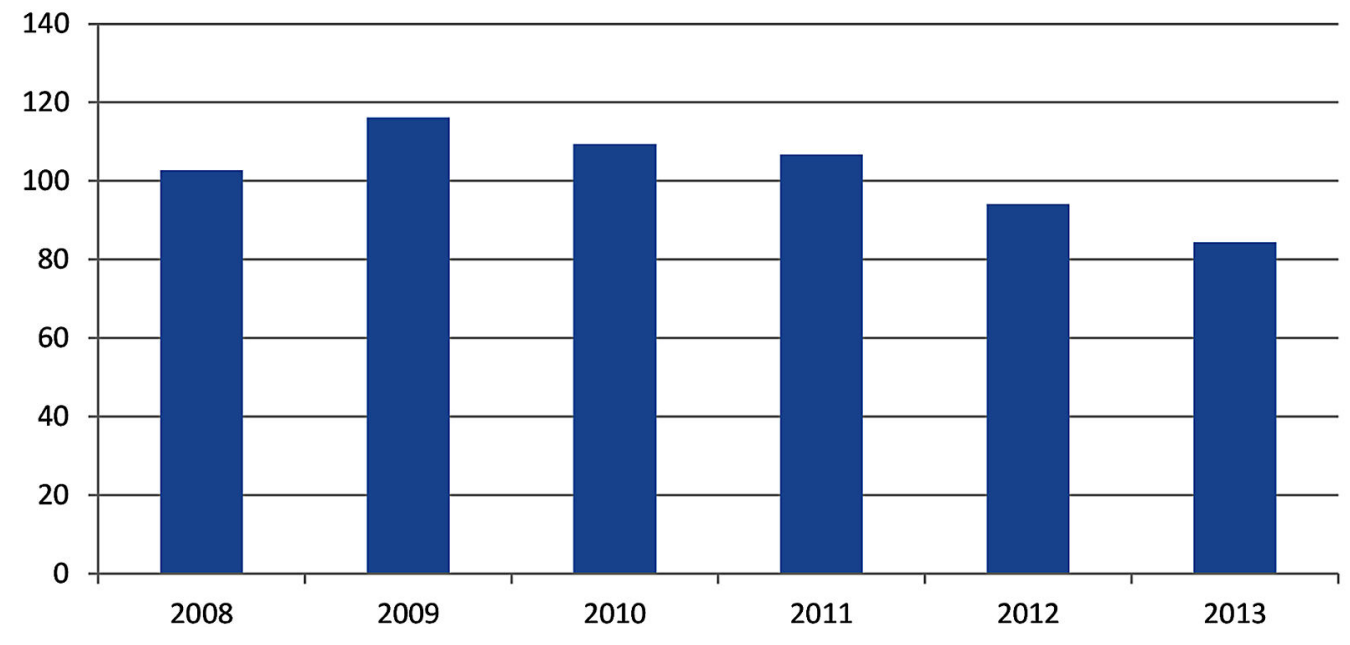

Figure 11. NIIP of Romania in the period 2008-2013 (in \% of GDP)

Source: European Commission, 2015e

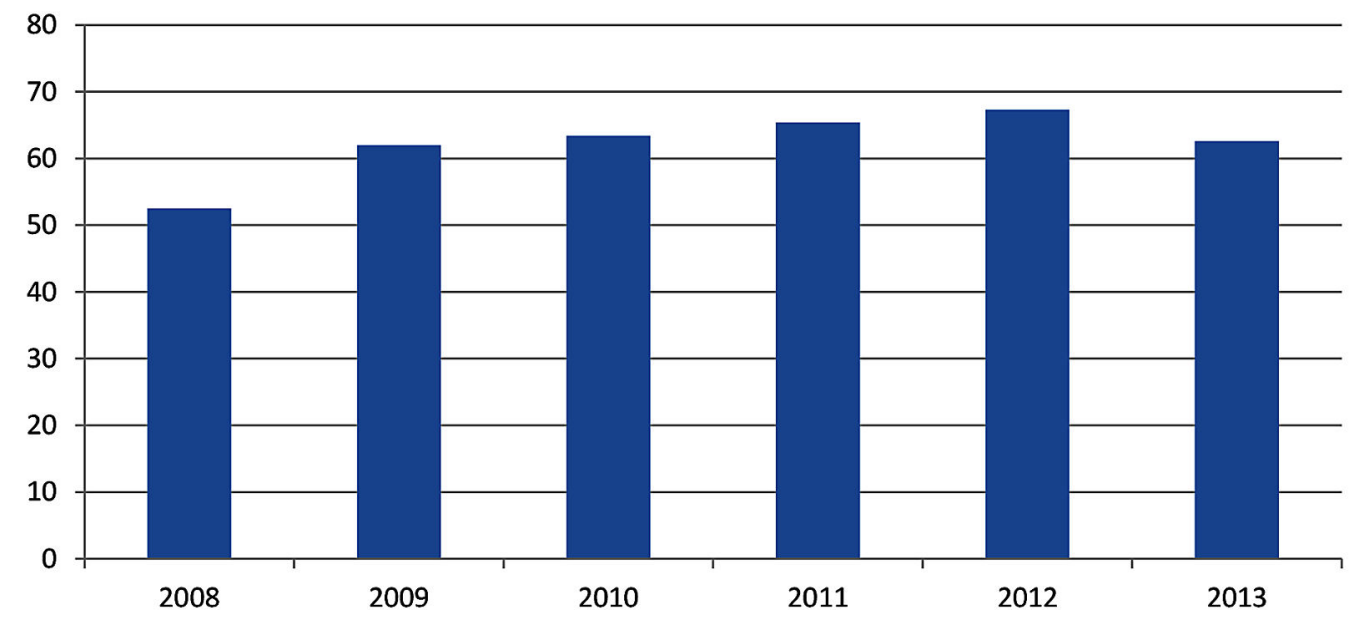

\section{Slovakia}

Slovak recovery from the crisis has been considered to be one the most successful in the EU. Such a quick recovery Slovakia owes to the GDP growth and relatively stable balance of payment position. However, the authors could hardly say that Slovak economy was not hit by the economic crisis. External debt recorded a substantial rise. In 2014, gross external debt share reached 82\% of GDP in 2013 comparing to 59\% in 2008. Such a trend was mainly driven by the public debt growth. Macroeconomic situation severely deteriorated in 2009. Fiscal deficit in 2009 amounted to 8\% of GDP. Performed fiscal consolidation resulted in a successful decrease of fiscal deficit that is limited up to 3\% in 2013 (European Commission, 2015f). According to the values of external sustainability indicators and current macroeconomic trends, Slovak external position could be assessed as relatively stable (Figure 12). 
Figure 12. NIIP of Slovakia in the period 2008-2013 (in \% of GDP)

Source: European Commission, $2015 f$

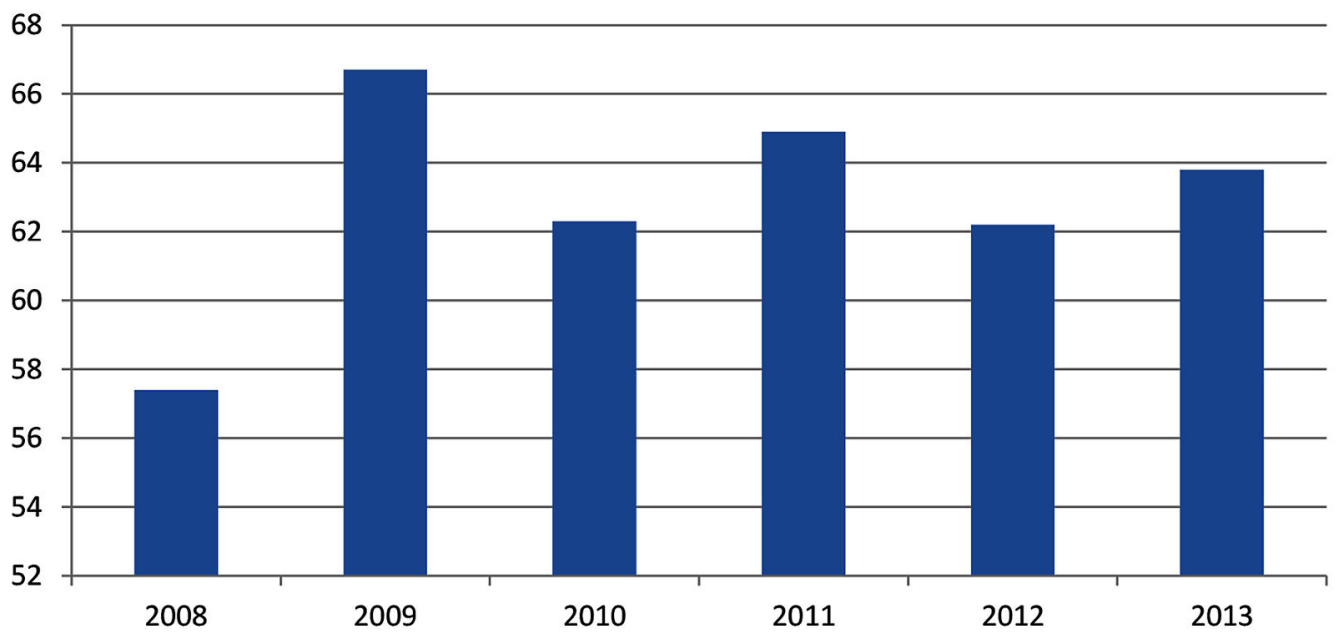

\section{Slovenia}

External sustainability of Slovenia seems to be finally under control. Economic crisis severely hit Slovenian economy. Unlike Slovakia that survived the initial shock, Slovenia is still suffering from the substantial deterioration of public finances, which resulted from sharp contraction of the economy, decrease in investments, and losses recorded by the state owned banks. Later, it was subsequently covered by the state through recapitalization. Consequently, Slovenia increased public debt from $22 \%$ of GDP in 2008 to $83 \%$ of GDP in 2015. In 2013, general government deficit amounted up to $14.6 \%$ of GDP (European Commission, 2015g). External sustainability was substantially influenced by the increase of public debt. Gross external debt in the absolute figures grew for less than $20 \%$ comparing to 2008 .

Figure 13. NIIP of Slovenia in the period 2008-2013 (in \% of GDP)

Source: European Commission, $2015 \mathrm{~g}$

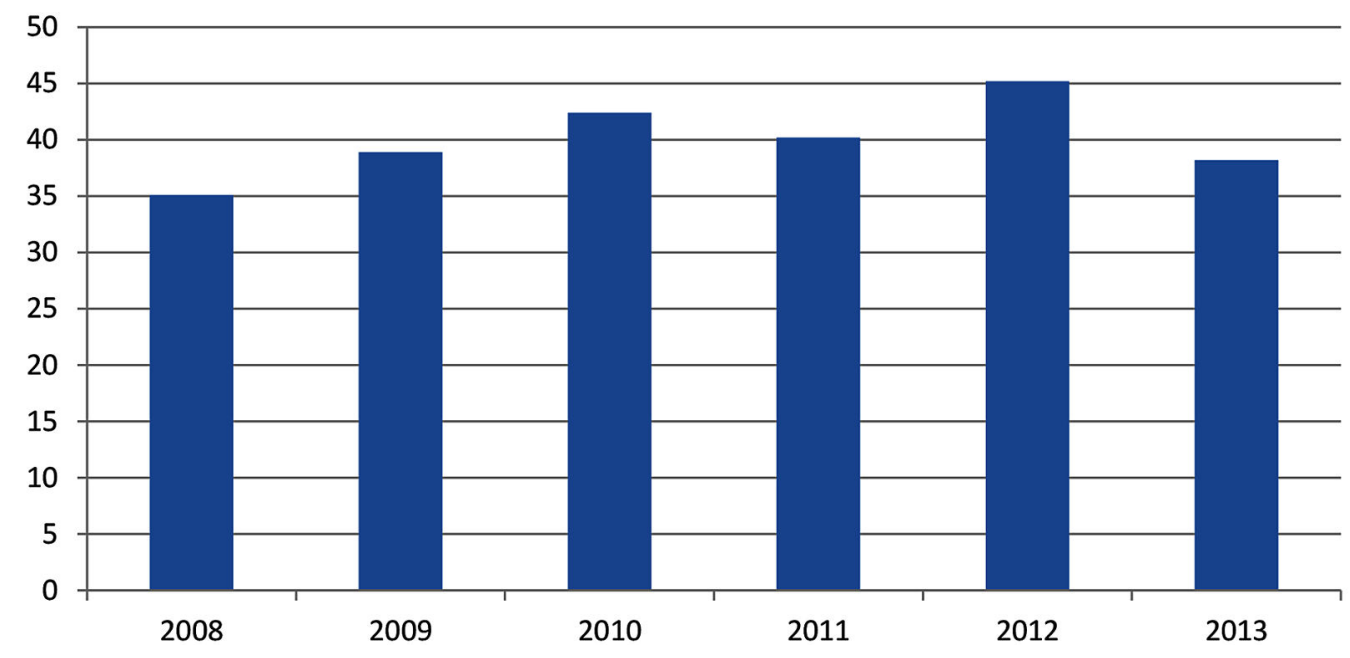


However, its structure is completely different. While in 2008 public component accounted for about $20 \%$ of the total gross debt, in 2014 almost two thirds of gross external debt is owed by the public or publicly guaranteed. In other words, public and publicly guaranteed debt accounts for $70 \%$ of GDP. Although the process of external debt sustainability deterioration lasted several years, there are some signals of slow recovery and stabilization. First, signs of recovery of consumption have been noticed. Second, export rose in 2014 for the first time since the crisis begun. NIIP has also been improved and amounted to $38.2 \%$ of GDP comparing to the all-time negative balance in 2012 of $45.2 \%$ (Figure 13). In the following period, recovery will depend on the success of proclaimed fiscal stabilization programmes, structural reforms as well as attraction of foreign direct investments.

\section{Serbia}

In 2014, share of gross external debt of Serbia was around 78\% of GDP. Its value is relatively stable since 2010 , but still just below the limit of $80 \%$, which is generally accepted as the point after which countries are referred to be highly indebted. Similarly to Slovenia, external debt structure was changed resulting from the two opposite tendencies: gradual rise of public debt and slow deleverage process of private sector. The good signal is a slightly improved current account balance. Exports rise was more dynamic comparing to the imports in the last years. Consequently, the debt to exports ratio amounted to $176 \%$. This is an encouraging trend since this indicator amounted to $271 \%$ of GDP in 2010, which has been the highest level ever. Latest NBS data indicate NIIP to be around 95\% of GDP, which is higher when compared to the peer countries (National Bank of Serbia, 2015a). Current situation requires close monitoring of the policy makers. Serbian economy is highly vulnerable in terms of external sustainability. Its growth perspectives will much depend on the success of fiscal stabilization programme recently adopted by the government.

\section{FUTURE RESEARCH DIRECTIONS}

In this chapter, current external debt level and trends in eight transition economies have been analysed. The analysis has proved that in all the observed countries external debt was rising by the same dynamic or even faster comparing to the economic growth. External debt rise was dominantly influenced by the rise of private external debt as in Hungary. However, public external debt also had a rising trend in some countries such as Hungary and Slovenia. During the crisis period, the sharpest rise of public external debt was recorded in Serbia and Croatia. Authors' results indicate that recent economic crisis has shown that external debt accumulation in the period of economic growth and prosperity may limit future possibilities for external financing in the crisis period. This is particularly true for public debt since use of debts for non-productive purposes may increase the debt share in GDP without any reasonable expectation for future growth. Very slow recovery of Serbian and Croatian economy is inversely correlated with the rise of debt. That could lead the authors to conclude that those countries experienced a debt trap situation. Also, authors' assumption is that a high level of corruption and non-productive use of external sources prevent Serbia, Croatia, and Slovenia to achieve economic recovery as it was the case in Slovakia and the Czech Republic, and even Hungary. The potential for future analysis may be to find out to what extent corruption and worsening of public external debt are correlated. Authors' premise, which should be proved, is that Serbia and Croatia accumulate external debt primarily due to undeveloped institutions and high level of corruption. 


\section{CONCLUSION}

During the transformation processes, which started in the beginning of the 1990s, transition countries implemented reforms in order to build economies based on market principles. Transition processes included economic opening, which resulted in FDI inflow, increase of both exports and imports, but also in accumulation of external debt. Although some countries, such as former Yugoslav countries, had already accumulated external debt in the previous period of communism, the amounts were not considered to be significant to hamper economic growth.

In the period until the financial crisis, all of the observed countries experienced external debt accumulation. It was slow, mainly a consequence of private sector debts and followed by growth of GDP and exports. Therefore, external sustainability indicators were relatively stable and external position was not jeopardized. However, as soon as the crisis occurred, external debt recorded a sharp rise. It was influenced by the rise of public debt. External sustainability indicators such as external debt to GDP, external debt to exports and NIIP substantially worsened, achieving critical points defined by the IMF and the World Bank, or results of the empirical research performed by various authors.

In this chapter, the authors analyzed external debt trends, determinants and sustainability indicators of eight transition economies. It is shown that, as a result of continuous debt accumulation, some countries such as Hungary, Slovenia, Croatia, and Serbia are facing serious risks in terms of external sustainability. Although crisis and economic contraction in the EU passed, external position in these countries is still vulnerable and influenced by the high government debts.

Authors' second conclusion is related to the general pattern of external debt accumulation, which is quite different in the observed countries. Success in transition reforms measured by the GDP and export growth is not correlated with the accumulation of external debt. Slovakia, for example, recorded a significant rise of external debt, especially in the crisis period, while the economy recovered quickly and external position is now stabilized. Slovenia experienced a sharp increase of external debt in the crisis period as well. However, government deficits in Slovenia are still high and have adverse impact to the overall external stability. Although having solid external sustainability indicators, Bulgaria, on the other hand, failed to achieve GDP growth and improve economic activity. All of these scenarios have shown that there should not be a unique approach when considering external sustainability of a country, but country's specific approach in order to capture specific risks and vulnerabilities.

\section{ACKNOWLEDGMENT}

Chapter is a part of projects 179001, 179015, and III 46006 funded by the Ministry of Education, Science and Technical Development of the Republic of Serbia, for the project period 2011-2015.

\section{REFERENCES}

Arnone, M., Bandiera, L., \& Presbitero, A. (2005). External Debt Sustainability: Theory and Empirical Evidence. Retrieved October 26, 2015, from http://core.ac.uk/download/pdf/9311316.pdf 
Bank of Slovenia. (2015). External Debt Statistics. Retrieved August 15, 2015, from www.bsi.si/en/ financial-data-r.asp?MapaId=982\#14091

Boljanović, S. (2013). A Sustainability Analysis of Serbia's Current Account Deficit. Economic Annals, 195(57), 139-171.

Buiter, W., \& Lago, R. (2001). Debt in Transition Economies: Where Is It Heading, What Can Be Done About It? Revue D'économie Financière (English Ed.), 6(H-S), 191-213.

Bunda, I. (2013). External Debt and Crisis Severity in CESEE. Paper presented at the $72^{\text {nd }}$ Jour Fixe of the OeNB, Joint Vienna Institute. Retrieved October 26, 2015, from www.jvi.org/fileadmin/jvi_files/ Economists/External_Debt_and_Crisis_Severity_in_CESEE_-_Irina_Bunda.pdf

Calvo, D. R., Stefanoudakis, J. H., \& Blanco Tames, J. M. (2009). External Debt and Economic Growth. Mälardalen University. Retrieved October 26, 2015, from http://mdh.diva-portal.org/smash/ get/diva2:236410/FULLTEXT01.pdf

Cordella, T., Ricci, L. A., \& Ruiz Arranz, M. (2010). Debt Overhang or Debt Irrelevance? IMF Staff Papers, 57(1), 1-24. doi:10.1057/imfsp.2009.20

Creedon, C., Fitzpatrick, T., \& Gaffney, E. (2012). Ireland's External Debt: Economic and Statistical Realities. Economic Letter Series, 2012(8), 1-7.

Croatian National Bank. (2015). External Debt Statistics. Retrieved August 10, 2015, from www.hnb. hr/dsbb/esdds-exd.htm

Cuestas, J. C., Gil-Alana, L. A., \& Regis, P. J. (2014). On the Changes in the Sustainability of European External Debt: What Have We Learned. Eesti Pank: Bank of Estonia. Retrieved October 26, 2015, from http://www.eestipank.ee/sites/eestipank.ee/files/publication/en/WorkingPapers/2014/wp03_2014.pdf

Czech National Bank. (2015). External Debt Statistics. Retrieved August 11, 2015, from www.cnb.cz/ cnb/STAT.ARADY_PKG.STROM_DRILL?p_strid=ADE\&p_lang=EN

Development Finance International. (2009). Heavily Indebted Poor Countries Capacity Building Programme: Debt sustainability indicators. London: Development Finance International.

European Commission. (2015a). Country Report Bulgaria. Commission staff working document, no. SWD(2015) 22 final. Brussels: European Commission. Retrieved October 26, 2015, from http://ec.europa. eu/europe2020/pdf/csr2015/cr2015_bulgaria_en.pdf

European Commission. (2015b). Country Report Croatia. Commission staff working document, no. SWD(2015) 30 final. Brussels: European Commission. Retrieved October 26, 2015, from http://ec.europa. eu/europe2020/pdf/csr2015/cr2015_croatia_en.pdf

European Commission. (2015c). Country Report Czech Republic. Commission staff working document, no. SWD(2015) 23 final. Brussels: European Commission. Retrieved October 26, 2015, from http:// ec.europa.eu/europe2020/pdf/csr2015/cr2015_czech_en.pdf 
Implications of Globalization on Growing External Debt in Eight Transition Economies

European Commission. (2015d). Country Report Hungary. Commission staff working document, no. SWD(2015) 36 final/2. Brussels: European Commission. Retrieved October 26, 2015, from http:// ec.europa.eu/europe2020/pdf/csr2015/cr2015_hungary_en.pdf

European Commission. (2015e). Country Report Romania. Commission staff working document, no. SWD(2015) 42 final. Brussels: European Commission. Retrieved October 26, 2015, from http://ec.europa. eu/europe2020/pdf/csr2015/cr2015_romania_en.pdf

European Commission. (2015f). Country Report Slovakia. Commission staff working document, no. SWD(2015) 44 final/2. Brussels: European Commission. Retrieved October 26, 2015, from http:// ec.europa.eu/europe2020/pdf/csr2015/cr2015_slovakia_en.pdf

European Commission. (2015g). Country Report Slovenia. Commission staff working document, no. SWD(2015) 43 final/2. Brussels: European Commission. Retrieved October 26, 2015, from http:// ec.europa.eu/europe2020/pdf/csr2015/cr2015_slovenia_en.pdf

Eurostat. (2015a). Database on Export of Goods and Services. Retrieved August 30, 2015, from http:// ec.europa.eu/eurostat/tgm/table.do?tab=table\&init=1\&language $=$ en \&pcode $=$ tec $00110 \&$ plugin $=1$

Eurostat. (2015b). Database on Gross Domestic Product at Market Prices. Retrieved August 28, 2015, from http://ec.europa.eu/eurostat/tgm/refreshTableAction.do?tab=table \&plugin $=1 \&$ pcode $=$ tec 00001 \&language $=$ en

Filipović, S., Raspopović, N., \& Tošković, J. (2015). Correlation between Reforms and Foreign Debt in Transition Countries. Industrija, 43(1), 175-191. doi:10.5937/industrija43-7709

Gligorov, V. (2004). Debt Sustainability and Growth in Croatia. Retrieved October 26, 2015, from http:// wiiw.ac.at/debt-sustainability-and-growth-in-croatia-p-276.html

Gros, D., \& Alcidi, C. (2011). Adjustment Difficulties and Debt Overhangs in the Eurozone Periphery. Brussels: Centre for European Policy Studies. Retrieved October 26, 2015, from www.ciaonet.org/attachments/18640/uploads

Helbling, T., Mody, A., \& Sahay, R. (2004). Debt Accumulation in the CIS-7 Countries: Bad Luck, Bad Policies, or Bad Advice? Washington, DC: International Monetary Fund.

Hungarian National Bank. (2015). External Debt Statistics. Retrieved August 14, 2015, from www.mnb. hu/en/statistics/statistical-data-and-information/statistical-time-series

International Monetary Fund. (2011). Public Sector Debt Statistics: Guide for Compilers and Users. Washington, DC: International Monetary Fund. Retrieved October 26, 2015, from http://unstats.un.org/ unsd/EconStatKB/Attachment475.aspx

International Monetary Fund. (2014a). Central, Eastern and South-eastern Europe: Regional Economic Issues. Washington, DC: International Monetary Fund. Retrieved October 26, 2015, from www.imf.org/ external/pubs/ft/reo/2014/eur/eng/pdf/ereo0414.pdf

International Monetary Fund. (2014b). External Debt Statistics - Guide for Compilers and Users. Washington, DC: International Monetary Fund. Retrieved October 26, 2015, from www.tffs.org/pdf/ edsg/ft2014.pdf 
International Monetary Fund. (2015a). Dissemination Standards Bulletin Board (DSBB). Washington, DC: International Monetary Fund. Retrieved August 15, 2015, from http://dsbb.imf.org/Pages/SDDS/ ExternalDebt.aspx

International Monetary Fund. (2015b). World Economic Outlook Database. Washington, DC: International Monetary Fund. Retrieved August 15, 2015, from www.imf.org/external/pubs/ft/weo/2012/01/.../ WEOApr2012all.xls

Jalles, J. T. (2011). The Impact of Democracy and Corruption on the Debt-Growth Relationship in Developing Countries. Journal of Economic Development, 36(4), 41-72.

Jošić, H. (2013). Comparative Analysis of External Debt Indicators in Croatia and Southeastern European Countries. Ekonomska Misao i Praksa - časopis sveučilista u Dubrovniku, 22(1), 197-220.

Lin, M. Y. (2014). The Sustainability of External Debt in OECD Countries: Evidence from Quantile Auto-regression. Research in World Economy, 5(2), 31-42. doi:10.5430/rwe.v5n2p31

Manzocchi, S. (1997). External Finance and Foreign Debt in Central and Eastern European Countries. Washington, DC: International Monetary Fund.

Mihov, I. (1999). The Economic Transition in Bulgaria 1989-1999. Fontainebleau: INSEAD. Retrieved October 26, 2015, from https://www0.gsb.columbia.edu/faculty/imihov/files/bgfinal.pdf

Miklos, G. (2011). The Hungarian Indebtness and Some Effects of the Crisis. Délkelet Európa - SouthEast Europe International Relations Quarterly, 2(7-Fall 2011), 1-10. Retrieved October 25, 2015, from www.southeast-europe.org/pdf/07/DKE_07_A_V_Miklos-Gabor.pdf

Milea, C. (2014). Romania's Foreign Debt: Trend, Structure, Indicators. Acta Universitatis Danubius (Economica), 10(6), 5-17.

National Bank of Bulgaria. (2014). Gross External Debt of Bulgaria. Retrieved October 26, 2015, from www.bnb.bg/bnbweb/groups/public/documents/bnb_publication/201401_s_ged_pub_en.pdf

National Bank of Bulgaria. (2015). External Debt Statistics. Retrieved August 12, 2015, from www.bnb. bg/Statistics/StDataDessiminationStandards/StDDSStandard/StDDSExternalDebt/index.htm

National Bank of Romania. (2015). External Debt Statistics. Retrieved August 16, 2015, from www.bnr. ro/External-Debt---BPM6-11335.aspx

National Bank of Serbia. (2015a). Balance of Payments. Retrieved August 16, 2015, from www.nbs.rs/ internet/english/80/platni_bilans.html

National Bank of Serbia. (2015b). External Debt Statistics. Retrieved August 16, 2015, from www.nbs. rs/internet/english/90/dug/index.html

National Bank of Slovakia. (2015). External Debt Statistics. Retrieved August 18, 2015, from www.nbs. sk/en/statistics/balance-of-payments-statistics/en-zahranicna-zadlzenost 
Ognivtsev, V. (2005). Bulgaria: Experience in Systemic Transition and Reforms. In S. Fernandez \& S. Laird (Eds.), UNCTAD Project Study: Coping with Trade Reforms: a Developing-country Perspective on the WTO Industrial Tariff Negotiations (pp. 139-160). Geneva: UNCTAD. Retrieved October 26, 2015, from www.unctad.info/upload/TAB/docs/TechCooperation/bulgaria_study.pdf

Pattillo, C., Poirson, H., \& Ricci, L. (2002). External Debt and Growth. Finance \& Development, 39(2), $32-35$.

Pogátsa, Z. (2009). Hungary: From Star Transition Student to Backsliding Member State. Journal of Contemporary European Research, 5(4), 597-613.

Reinhart, C. M., \& Rogoff, K. S. (2010). Growth in a Time of Debt. The American Economic Review, 100(2), 573-578. doi:10.1257/aer.100.2.573

Schclarek, A. (2004). Debt and Economic Growth in Developing and Industrial Countries. Lund: Lund University. Retrieved October 26, 2015, from https://lup.lub.lu.se/luur/download?func=downloadFile $\&$ recordOId $=1387405 \&$ fileOId $=2061440$

Šimić, V., \& Muštra, V. (2012). Debts (Public and External) and Growth - Link or no Link?[CRORR]. Croatian Operational Research Review, 3, 91-102.

Tiruneh, M. W. (2004). An Empirical Investigation into the Determinants of External Indebtedness. Prague Economic Papers, 3(3), 261-277. doi:10.18267/j.pep.242

United Nations Conference on Trade and Development. (2001). World Investment Report 2001: Promoting Linkages. Geneva: United Nations publication. Retrieved October 26, 2015, from http://unctad.org/ en/Docs/wir2001_en.pdf

Uvalić, M. (2010). Transition in Southeast Europe: Understanding Economic Development and Institutional Change. Helsinki: UN University, UNU-WIDER. Retrieved October 26, 2015, from www.wider. unu.edu/publications/working-papers/2010/en_GB/wp2010-41/

Uzun, A., Karakoy, C., Kabadayi, B., \& Emsen, O. S. (2012). The Impacts of External Debt on Economic Growth in Transition Economies. The China Business Review, 11(5), 491-499.

Vlahinić Dizdarević, N., Buterin, V., \& Žagar, A. (2006). The External Debt Sustainability in Southeast European Countries: The Analysis of Debt Indicators. In Proceedings of the III International Conference "From Transition to Sustainable Development: the Path to European Integration".Sarajevo: School of Economics and Business.

\section{ADDITIONAL READING}

Baum, A., Checherita Westphal, C., \& Rother, P. (2013). Debt and Growth: New Evidence for the Euro Area. Journal of International Money and Finance, 32, 809-821. doi:10.1016/j.jimonfin.2012.07.004 
Becker, T., Daianu, D., Darvas, Z., Gligorov, V., Landesmann, M., Petrovic, P., . . Weder Di Mauro, B. (2010). Whither Growth in Central and Eastern Europe? Policy Lessons for an Integrated Europe. Bruegel Blueprint Series, 11. Retrieved October 26, 2015, from http://bruegel.org/wp-content/uploads/ imported/publications/101124_bp_zd_whither_growth.pdf

Dias, J. D. (2010). External Debt Statistics of the Euro Area. In Proceedings of IFC Conference "Initiatives to Address Data Gaps Revealed by the Financial Crisis". Basel: Bank for International Settlements. Retrieved October 27, 2015, from www.bis.org/ifc/events/5ifcconf/dias.pdf

International Monetary Fund. (2002). Assessing Sustainability. Washington, DC: IMF. Retrieved October 27, 2015, from www.imf.org/external/np/pdr/sus/2002/eng/052802.pdf

Kraay, A., \& Nehru, V. (2004). When is External Debt Sustainable? Washington, DC: World Bank. Retrieved October 26, 2015, from http://siteresources.worldbank.org/INTDEBTDEPT/DataAndStatistics/20263265/When-is-Debt-Sust.pdf

Kregel, J. (2006). Rethinking Debt Sustainability in the Context of the Millennium Development Goals. BNL Quarterly Review, 242(59), 225-248.

Krugman, P. R. (1988). Financing vs. Forgiving a Debt Overhang. Journal of Development Economics, 29(3), 253-268. doi:10.1016/0304-3878(88)90044-2

Rossini, G., \& Zanghieri, P. (2009). Current Account Composition and Sustainability of External Debt. Applied Economics, 41(5), 677-683. doi:10.1080/00036840601007427

Roubini, N., \& Wachtel, P. (1998). Current Account Sustainability in Transition Economies. Cambridge, MA: National Bureau of Economic Research. Retrieved October 26, 2015, from www.nber.org/papers/ w6468.pdf

World Bank. (2012). Global Development Finance: External Debt of Developing Countries. Washington, DC: World Bank.

Wyplosz, C. (2011). Debt Sustainability Assessment: Mission Impossible. Review of Economics and Institutions, 2(3-Fall 2011), 1-37.

\section{KEY TERMS AND DEFINITIONS}

Debt Sustainability: A situation in which a borrower is expected to be able to continue servicing its debts without an unrealistically large future correction to the balance of income and expenditure.

Economic Growth: An increase in the inflation-adjusted market value of the goods and services produced by an economy over time.

External Debt Service: Funds required to cover the repayment of interest and principal on external debt.

Globalisation: A process of international integration arising from the interchange of world views, products, ideas and other aspects of culture.

Gross External Debt: Contingent, liabilities that require payment(s) of principal and/or interest by the debtor at some point(s) in the future and that are owed to non-residents by residents of an economy. 
Net External Debt: Gross external debt adjusted for external assets in debt instruments.

Net International Investment Position: A difference between a country's external financial assets and liabilities.

Transition Economies: Economies, which experience change from a centrally planned economy to a market economy. 